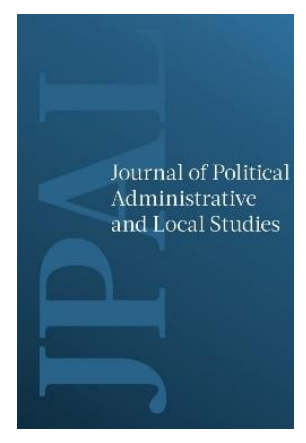

\title{
JOURNAL OF POLITICAL ADMINISTRATIVE AND LOCAL STUDIES
}

\author{
October 2019, Vol:2, Issue:2 Ekim 2019, Cilt:2, Sayl:2
}

ISSN: $2636-803 X$

journal homepage: www.jpaljournal.org

\begin{tabular}{|c|c|}
\hline \multicolumn{2}{|c|}{$\begin{array}{c}\text { THE NEW CHALLENGES OF THE SCO AND } \\
\text { TURKEY-SCO RELATIONS }\end{array}$} \\
\hline E INFO & ABSTRACT \\
\hline $\begin{array}{l}\text { Keywords } \\
\text { SCO, CSTO, Turkey, China, } \\
\text { Russia, Central Asia }\end{array}$ & $\begin{array}{l}\text { This paper studies the Shanghai Cooperation Organization } \\
\text { (SCO)'s objectives, its expanding process, the advantages and } \\
\text { disadvantages of the new and old member states and SCO- } \\
\text { Turkey relations. There is an increasing political and } \\
\text { economic rivalry between SCO's two important members } \\
\text { (China and Russia). This study shows that China and Russia } \\
\text { have different policies to contol the Central Asia. Russia has } \\
\text { attempted to increase its influence in the region with the help } \\
\text { of the Collective Security Treaty Organization (CSTO), while } \\
\text { China aims to do it with the help of the SCO. On the other } \\
\text { hand, Turkey has increased its impact in the Central Asia } \\
\text { policy and Turkey-SCO close relations will also play a } \\
\text { significant role both in the SCO and Central Asia politics. It is } \\
\text { also examined that the SCO policies are majorly driven by } \\
\text { China. Thus, Chinese and Russian political and economic } \\
\text { rivalry is concerned to deteriorate SCO functions. }\end{array}$ \\
\hline
\end{tabular}

DOI: https://doi.org/10.37460/j.2636-7823/2019.2.2.03

\section{INTRODUCTION}

For centuries, in Central Asia both world and regional powers have sought to increase their political, economic and military effects. While world powers have different policies for this region, the main concern of the regional countries is the threat to the security of their borders (Kuralai, 2013). After the disintegration of the Soviet Union, this threat remained as a main issue for the Central Asian countries, particularly for China and Russia that have long borders with Central Asian countries. 
Central Asia is relatively an unstable region, and this unstable situation of the region has not only affected the Central Asian countries' interests, it also affected the national interests of the Central Asian neighbor countries such as China, Russia, Iran, Pakistan, Afghanistan, and even Turkey's. Since the disintegration of the Union of the Soviet Socialist Republics (USSR), China has been actively seeking to increase its military, political and economic influence in Central Asia (Thrassy, 2009). On account of this policy, China has attempted to form an organization to protect its borders, with the engagement of the neighbor countries such as Russia, Kazakhstan, Uzbekistan, Kyrgyzstan. Finally, China and Russia established the Shanghai Cooperation Organization (SCO) under the leading role of China.

This study attempts to analyze SCO's development process, its opportunities and challenges and evaluate Turkey's current SCO position. It is claimed that the SCO is developing under the targets of Chinese Foreign Policy rather than those of Russian and other member states. China and Russia have cooperation for Central Asian security, political and economic stability, but in the long term, they have different political and economic policies for this region, they both want to increase their influence via organizations or bilateral relations in the region. With the accession of India and Pakistan to the SCO, the interest based policies turned to be more complicated. Therefore, the question raised here: is Chinese and Russian political and economic competition will affect Central Asia and SCO?

This study is composed of five sections. The first section is introduction, the second section attempted to explain the SCO's structure and its political and economic objectives, two main bodies of the SCO (the SCO Secretariat; SCO Executive Committee of the Regional AntiTerrorist Structure) and the Collective Security Treaty Organization (CSTO). The third section studies the challenges and advantages of SCO, the political and economic competition between China and Russia. The fourth section analyses SCO-Turkey relations; the significance of Turkey's geo-strategic position for SCO and related countries economic interests and energy requirements. The last section concludes the study.

\section{The Structure and Objectives of the SCO}

\subsection{SCO}

The Shanghai Cooperation Organization (SCO) is an intergovernmental organization which was established on 15 June 2001 in Shanghai (China). It was founded by the People's Republic of China, the Russian Federation, the Republic of Kazakhstan, the Kyrgyz Republic, the Republic of Tajikistan, and the Republic of Uzbekistan (Aris, 2013). Before, it was known the Shanghai Five mechanism that was founded in 1996. Its Charter was signed in St. Petersburg 
(Russia) during the SCO Heads of State meeting in 2002. It has entered into force in 2003 within its targets, principles and core activities.

With the disintegration of the Soviet Union, China and the leaders of the newly independent states of Kazakhstan, Uzbekistan, Kyrgyzstan, and Tajikistan found themselves in the position of having to negotiate the settlement of territorial disputes and border demilitarization. As both with its Central Asian leadership role and continued practical influence in the region. Russia was also invited to participate in these negotiations. This process can be seen as an example of China's border policy aimed at ensuring friendly relations and stability within the states, As well as ensuring safety for China's western borders. In the SCO Convention it was insisted that member states respect the "inviolability of borders" and also support and protect the stability of Xinjiang, China's westernmost region (Grace, 2016).

The main goals of the SCO are strengthening mutual trust among the member and neighbor states, promoting their effective cooperation in politics, trade, economy, research, technology, culture, education, energy and environmental protection, as well as ensuring peace, security and stability in the region. Its external policy is based on the principles of openness and nontargeting any third country's domestic affairs (SCO, 2017). Not targeting to intervene any other countries domestic affairs is also one of the most important principles of the Chinese foreign policy. SCO is comprises a large geographic area, occupying a territory of around 27,406,927 square kilometers of Asia, and also comprising a quarter of the world's population (Hasnat and Awan, 2016).

SCO is Originally established as a security cooperation forum to demilitarize borders among the member states. In 2001 SCO Convention, it was declared in the first article that SCO was established to fight against "Three Evils" (Terrorism, Separatism, and Extremism) (Allison, 2018). These "Three Evils" have also formed the core center of China's domestic and foreign policy. SCO's goals and agenda have since broadened to include increased military and counterterrorism cooperation with sharing information among the member states. Recently, it has also increased its focus on regional economic developments such as China's the Belt and Road Initiative and Russia's the Eurasian Economic Union (Albert, 2015). Recently, SCO is considered to be used for the security of these economic initiatives.

The SCO has two permanent bodies, these two bodies comprise SCO's fundamental structure. The first one is the SCO Secretariat in Beijing; the second one is the SCO Executive Committee of the Regional Anti-Terrorist Structure (RATS) in Tashkent. It is interesting that none of these important bodies are thought to be in Russia. 
Fig.1. the two permanent bodies of the SCO

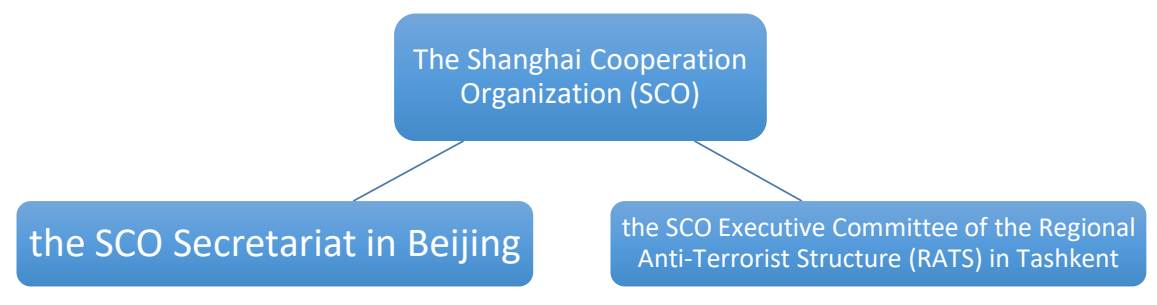

Resource: Author's own resource.

The SCO's this structure shows that the SCO was formed in accordance with China's border strategy and counterterrorism policy. the SCO's policy is majorly driven by China rather than Russia and other SCO Member States. When evaluating the future of Chinese multilateral engagement, it is important to distinguish between different forms of Chinese multilateral engagement. Contrary to China's claims, the SCO's objectives are largely influenced by Chinese policy objectives. Even some analyses show that China is able to leverage its influence on the SCO and ensure that sensitive issues to be formed in accordance with Chinese Communist Party objectives (Grace, 2016). However, the actualization of such a situations is harder than before, before do this, China should take into consideration India and Pakistan as well.

Fig. 2. SCO Member, Observer and Dialog Partner States

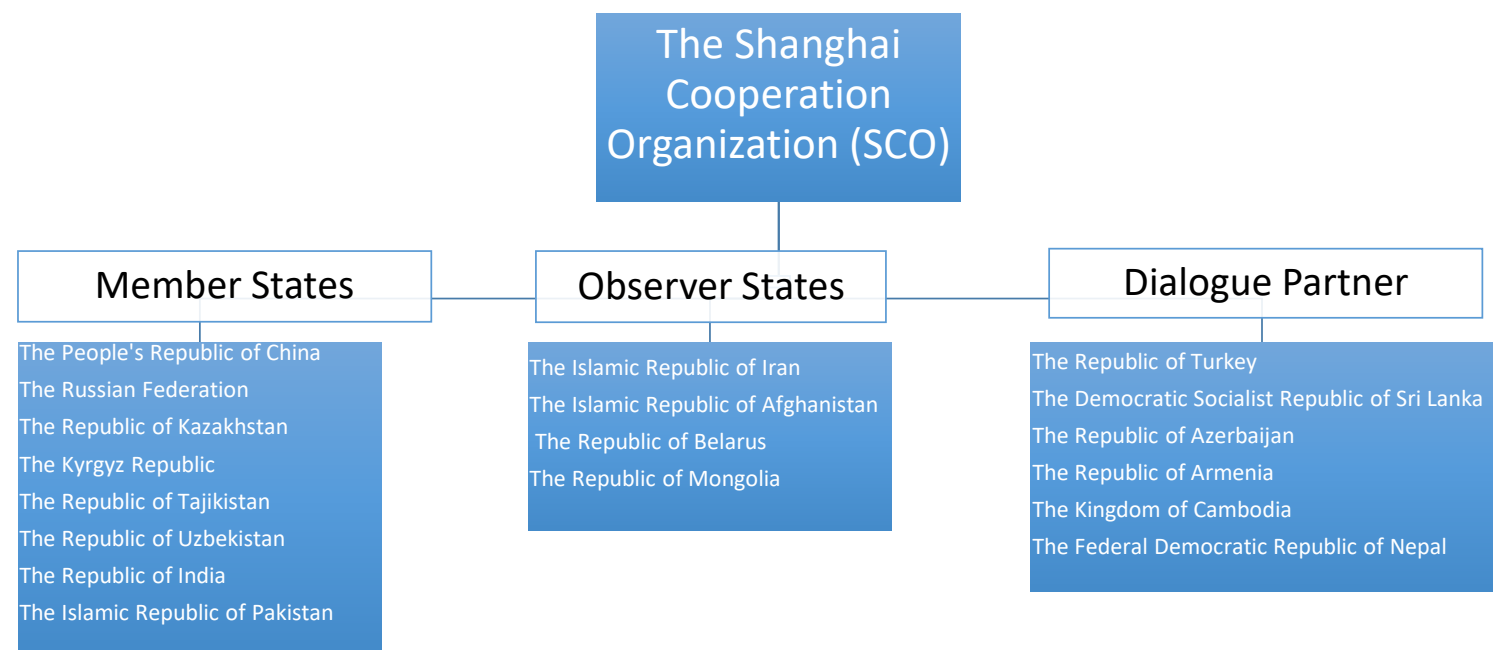

Resource: Author's own resource.

In SCO's Astana summit in June 2017, India and Pakistan were accepted as full-fledged SCO members and unconditional signatories to all SCO documents. Belarus was upgraded from 
Dialog Partner status to the Observer State status, and also Armenia, Azerbaijan, Cambodia, and Nepal were accepted as new dialogue partners. With the accession of India and Pakistan, the SCO has become the world's one of the largest association in terms of area, population, and economic potential. Currently, China, Russia, India and Pakistan are also four nuclear powers in the SCO (Alimov, 2018). Although, this makes SCO be much more important in the context of the East-West power competition. However, it also brings the risks of interest conflicts among these important members for Central Asia future.

Currently, China and Russia both are the locomotives of the SCO, However the rapid economic growth have propelled China onto the world's stage. Some analyst believe that China-Russia relations have deepened by necessity rather than a sense of mutual trust. Apart from their own interests, China and Russia cautiously approach to the new politic and economic engagements. China believes that SCO expansion would infuse fresh vigor into the group's future development in the international arena. While Russia sees the addition of India and Pakistan as a chance to increase both the bloc's political and economic potential. However, smaller SCO members are concerned to be squeezed by the interests of China and Russia (Aris, 2013). Another important point should be taken into account is the recent economic rivalry between China and Russia based on China's the Belt and Road Initiative (BRI) and Russia's the Eurasian Economic Union (EAEU), these two projects aim to fulfill and link their economic policies with SCO Members, Observer countries and Dialog Partner countries. In recent years, in particular, SCO has attracted a significant attention in the world, with its potential role in a counterbalance to the USA and its recent increasing engagement with India, Pakistan and Iran. One of the most important reasons of SCO's wiling to build good relations with Iran, India and Pakistan. These kind of favourable political and economic bilateral developments are basically focused on marketing, trade, energy and infrastructure developments in the Central Asia (Norling and Niklas Swastrom, 2007).

\subsection{CSTO}

Central Asia was under the influence of Tsarist Russia and the Soviet Union, for about two centuries. With the disintegration of the Soviet Union in 1991, Central Asian states became independent, this important issue has forced Russian governments to find new ways to manage the region. in fact, the region was used to be solely influenced by Soviet Union, but in the last 20 years, the region has been gradually penetrated by American and Chinese influence. Having been influenced by different powers political and economic policies, the region has faced crucial issues such as security threats, religious extremism and narcotics smuggling (Frost, 
2009). Central Asian Countries surely would not be pleased with this situation, but because their political and economic weakness, they approved to be collected in an organization that supported by the world powers to overcome the threats and challenges of the region.

Except for having a leading powerful country potential for the region, Russia also has important benefits in the region and it has strong motivation to implement an active policy of engagement. Russia probably will not be willing to see a new great power enter its traditional realm that was ruled by itself for a long time. Furthermore, the attitudes among the Russian elites towards the cooperation with China are divided. Some thinks that China is a strong ally against the United States while others yearn for an alliance with the United States against China's increasing influence. This dissention may create an ambivalence and sometimes cause contradictory behaviors in Russian-Chinese cooperation (Kazantsev, 2014). Since Russia afraid of the increasing influence of China in the Central Asia with the establishment of SCO, Russia tried to find alternatives for Central Asia under its leadership and established CSTO.

The Collective Security Treaty (CST) was signed in 1992 in Tashkent, by the Heads of six countries (Russia, Armenia, Kazakhstan, Kyrgyzstan, Tajikistan and Uzbekistan, Subsequently, Azerbaijan, Georgia and Belarus has also joined), in 2002, it was transformed to the Collective Security Treaty Organization (CSTO) and it came into force in 2003 (Belarusian Diplomatic Service, 2019). The CSTO was thought to be an organization to fight against terrorism and make sure security of the Central Asia and Eurasia. Although CSTO's main principles are similar to SCO's main principles, However, it was not able to create a big interest in the world such as NATO and SCO did.

When we look at the dynamics of Central Asia for recent years, we can easily see that China and Russia have tried to cooperate with Central Asian countries by forming organization in order to make their borders safer and increase their influence in the region. However, with the establishment of the SCO, the security of the region was developed under the influence of China rather than Russia's. the main reasons of China's increased influence are Chinese economic growth, China's energy requirement (which is very important for energy supply countries) and Chinese promoting financial, investment, infrastructure and trade projects for the region in the name of Belt and Road Initiative and Asia Infrastructure Investment Bank.

\section{The competitive challenges of the SCO}

Why do China and Russia need to cooperate by establishing or joining an international 
organization? Rationalist theories of international relations believe that institutions are created by states as a solution of the strategic dilemmas. Moreover, due to their power structures and different political and economic interests, states may face different strategic situations (Song, 2014). According to the classic ideas of political realists in the theory of international relations, foreign affairs are a struggle for power between states based on compelling national interests (Snyder, 2004). China and Russia both cooperate to make Central Asia more stable, however, they have different expectations from this region. Due to the interests such as political power, economic superiority and energy requirements, Chinese and Russian different interests may create conflicts in the Central Asia and SCO.

Although, The SCO does not seek sovereign control over its member states or enforce its decisions and recommendations to them. However, SCO does not have a formal decision making procedure as well. It operates on the basis of informal discussion, and consensual approval for a decision to be adopted. Therefore, some analysts argue that Chinese and Russian political, economic and energy based interests and the rivalry between them are likely to deteriorate SCO cooperation (Hasnat and Awan, 2016). This competition is likely to create disturbance between landlocked Central Asian Countries, Pakistan and India as well. India, for instance, with its sharply growing economy is also likely to be a part of this competition.

Another important challenge is the competition between China and Russia in the context of China's the Belt and Road Initiative (BRI) and Russia's the Eurasian Economic Union (EAEU). The strategy of these two projects are designed to strengthen their regional influence. These two countries' economic interests are quite far from each other's. The second challenge is the expansion of the SCO which is likely loss efficiency of the development and common approaches to the regional security objectives. The third one is the deep tensions between India and Pakistan; the competition between India and China could also have a negative impact on the initiatives and the handling of negotiation on the agreements. The fourth challenge is having involved with interest competition, the SCO is likely to ignore the interests of the smaller SCO members (Alimov, 2018). In the current circumstances such as ISIS-sponsored terrorism across the line of Pakistan and Afghanistan, the Indian state-terrorism and human rights violations in Jammu and Kashmir will probably make the SCO Anti-Terrorist Structure extremely hard to manage (Norling and Swastrom, 2007). On the other hand, Afghanistan's unstable position is a serious factor, especially, after the announcement of Us and NATO wanted to withdraw their military forces from Afghanistan. This could prevent the creation of stable conditions for economic development. 
The biggest obstacle for China to create her influence is the deep connection between Russia and Central Asian countries, which have an extensive network of historical, cultural and institutional ties. All SCO members are members of both organizations, except China. Russia is certainly not happy to see another grate power to enter her dominant realm. The attitude of Central Asian states towards China is also not clear, because they need to calculate the perceived benefits of cooperation with their great eastern neighbors. As a newly arrived to the Central Asia politics, China, could face major challenges, including doubts and distrust of the partners. Thus, China is using the SCO as a tool to compete with existing organizations in the region.

With the help of SCO, Russia hopes to be able to monitor the security contacts between China and Central Asian states as well. Russian-Chinese relations in Central Asia are multidimensional, their relations are based both on competition and cooperation. Russia aims to maintain its leadership during the gradual expansion of the SCO. Therefore, Moscow acts as representing the post-Soviet Central Asian states against China. Russia wants to prevent the SCO to dominate Central Asia and slowdown the integration and cooperation within the SCO. Russia aims to keep all organizations operating in this region equal to those that are controlled by Moscow. Russia thinks that possible cooperation between the CSTO, EURASEC and the SCO should strengthen Russia's role in Central Asia and maintain Russian sovereign ties in the region (Kaczmarski, 2007). In 2006, when President Putin proposed "energy club" at the SCO, Chinese policy makers and analysts were initially quite pleased with this idea, but they soon thought that it was just an another Russian tactic to increase Russia's Central Asian influence and control energy resources. Despite the frequent summits and negotiations that China and Russia claim to form a partnership based on mutual trust and long-standing strategic cooperation, the Chinese and Russian energy and economic cooperation in Central Asia is full of doubt and it is described to be difficult to bargain (Song, 2014).

The issue of security in Central Asia is still more complexed and remains open for discussion. Other major concerns are the zones and disputed territories, the presence of which impedes the full-fledged implementation of the region's economic and energy potential and the emergence of new agreements for long-term development (Alimov, 2018). The claim for Taliban for instance, getting support from the border areas of North Western tribal of Pakistan. India has issues with Bangladesh, Nepal and Sri Lanka. It also has problems with Bhutan and Burma over Nagaland and Assam separatists (Hasnat and Awan, 2016). We know that SCO did not do anything tangible when disputes between Uzbekistan and Kyrgyzstan broke out in 2010. Thus, 
the question raised here is what can SCO do when these countries face to these kind of conflicts?

During the latest SCO Summit in 2018 in Qingdao, China has opened a new page for the development of the Organization for SCO's growing importance role in the global affairs. The SCO was conceived some levels of cooperation such as the cooperation in politics and security, in trade and economic activities and in the development of cultural and humanitarian ties. According to China's President Xi, an expanded SCO is more likely to have a better position in the regional security heavyweight (Tiezzi, 2014). Another important point is the creation of an "SCO Development Fund" which is currently discussed and establishment of which is considered to be supported by every member state. With the accomplishment of this fund, the SCO agreed projects can implement faster and easily (Aris, 2013).

In 2006, President Putin proposed "Great Eurasian Partnership" as a new vision for economic and energy cooperation in Eurasia. This considered to create a network of bilateral and multilateral trade agreements between the EAEU, China, India, Pakistan, Iran, and other interested countries. President Putin also called for an "energy dialogue, integration of national energy concepts, and the creation of an Energy Club." Following, member states discussed to establish a "unified energy market" for energy exports. SCO member states Kazakhstan and Russia together with Turkmenistan are possessed world's largest reserves of oil and natural gas, driving interest in expanded energy cooperation among members. Russia has also signed agreements with some Central Asian states to build gas pipelines. Currently, China is also giving more priority to its energy relations with Central Asian Countries. Central Asia-China Gas Pipeline for instance is running more than 1,100 miles through Uzbekistan and Kazakhstan to China's Xinjiang Uighur Autonomous Region. China has pledged around \$16 billion fund to integrate the region and revive China's Silk Road Economic Belt. By doing this, China aims increase its political and economic influence in the region, at the same time weaken Russia's traditionally dominant influence in the Central Asia (Albert, 2015).

The SCO lies at the center of economic initiatives. Therefore, some experts believe that it will be crucial to determine the path of Eurasia's future development. In this context, the academic community increasingly uses the term "Eurasian design" that a new system of regional integration process within the framework of the EAEU and BRI. As President Putin has stated in 2017. "Eurasian partnership is not just a new engagement among the countries and economies, It also targets to bring peace and stability to Eurasia by changing the region's political and economic scenery" (Albert, 2015). With this statement, it can be understood that EAEU and BRI have many common and different expectations for Central Asia and the attitude 
of Central Asian states will be crucial for Chinese and Russian future policies.

\section{The significance of the SCO-Turkey relations}

With the end of the Cold War, Eurasia has undergone many political and economic changes, parallel to this change, Turkey became an important country in the Eurasia politics. Turkey has increased its political and economic importance and developed important relations with Central Asia countries as well (Çeviköz, 2016). In the meantime, China and Russia made new policies for bilateral trade and investment, they became Central Asia's major trade partners. Compared to China and Russia's progress in the Central Asia politics, Turkey's self-assumed leadership over Central Asia had few progress.

Turkey is another important actor in Central Asia politics, in these region Turkey has political and economic interests as well. Recently, Turkey has developed closer relations with Central Asia Countries, China and Russia. Turkey does not want to ignore establishing good relation with Central Asia countries and with its related organizations. Therefore, for Turkey, SCO's developing process is much more important than before and Turkey wants to take a place in SCO and be more active in the Central Asian politics.

For the last 15 years, Turkey has interested in the accession to the SCO. Since then, this was mentioned several times by President Erdoğan. Thereafter, Turkey applied for SCO observer country status, but it was not successful. Following, Turkey's application for the SCO's Dialogue Partner Status in March 2011 was successful, and Turkey in June 2012 became Dialog Partner of the SCO (Eren, 2017).

When considering Turkish foreign policy in the contest of the multilateral foreign policy, we can see that Turkey is the only NATO member country which has built institutional relations with SCO (Turkey become Dialogue Partner of SCO). It is very important that Turkey got the ability to establish relations with these two organizations which are considered to be the most important strategic rivals of each other in today's world politics (Erşen, 2015). Turkey-SCO closeness is important for fighting against terrorism which is essential for Middle East and Central Asian Countries' security. Although the SCO has not agreed on a common list of terrorist organizations, but the counterterrorism is one of the most important concept for Turkey and SCO (Üngör, 2013).

Turkey has historical, linguistic and religious affinity with Central Asian states, since the independence of this countries, Turkey has invested in infrastructure, education and health for these countries, moreover, Turkey has developed cultural links among these countries. Thus, 
Turkey has played an important role in political, economic, cultural and strategical development of this region (Kalra and Saxena, 2006). Turkey has political, economic and energy based strategic relations with Russia, in particular the future of the Syria. Turkey has developing economic and trade relations with China, especially cooperation relations with China for the construction of the Belt and Road Initiative.

In the expanding process of the SCO, Turkey has remained SCO Dialogue Partner, while Pakistan and India were accepted as full members and Belarus was upgraded from Dialogue Partner status to the Observer Country status. Some analysts think that Turkey's full SCO membership seems a distant scenario, depending on the evolution of the SCO's geopolitical vision and identity as well as Turkey's NATO membership. In 2013, Turkish then Prime Minister Erdoğan refueled the controversy of Turkey's "axis shift" when he said that Turkey might consider dropping its bid for EU membership if SCO accept Turkey as a full member.

As a result of the political and economic dynamics, Turkey has adopted its own political and economic strategies both in domestic and international politics (Tezcür and Grigorescu, 2014). For last 20 years, Turkey is considered to be critical country for energy transportation between Asia, Europe and Middle East (Wuensch, 2015). Turkey’s this potential motivated Turkey to have multilateral policies not just limited with regional states, but also made Turkey establish important relations with international organizations.

Turkey has significant role in "China-Central-West Asia Economic Corridor" (CCWAEC). Turkey is an essential security actor for China, and it has an important role in Eurasia and Middle East politics. China-Turkey cooperation may have positive influence on the stability of Xinjiang which is vital for the stability of the Central Asia and the succession of the BRI (Y1ldırımçakar, 2019). Therefore, it is expected that China, Russia and SCO other members support Turkey's SCO membership, at least support Turkey to be an observer country for SCO summits.

Central Asian countries such as Kazakhstan, Uzbekistan, Kyrgyzstan, Turkmenistan and Tajikistan have religious, cultural and ethnical relations with Turkey. Turkey's SCO membership is very important for China's "One China" policy and for the security of the BRI. In 2012, when Chinese President Xi visited Turkey, he said that: "Mister President Erdoğan! You obviously stated that, Turkish Government will not allow any activity be organized in Turkey which may be considered as a threat against China's independence, sovereignty and territorial integrity. Chinese part is content with your this policy” (Ekrem, 2012). Moreover, Turkey has developing political, economic and military relations with Pakistan and Iran 
( Recently Pakistan bought 30 Turkish made helicopters) (Pakistan Defence Forum, 2018). Currently, Iran is an observer country in SCO, while Pakistan and India became full member of the SCO in 2017. An expanded and a comprehensive SCO is expected to facilitate the BRI implementation process, enhance the relations between Turkey-China, Turkey-Central Asia and Turkey-SCO members states.

Turkish former Prime Minister Ahmet Davutoğlu has claimed that, Turkish Government aims to make Turkey be a more powerful country and handle its historical mission on the geostrategical position at the center of Middle East, Europe and Eurasia, to be a pacifist actor both regionally and globally, and Turkey will work very hard for global peace and regional stability (Davutoğlu, 2010). Therefore, Turkey aims to keep its NATO membership position, at the same time be a member of SCO. parallel to this policies, Turkey aims to obtain a more active role both in Western and Eastern politics and contribute the global peace and stability more than Turkey used to do.

President Erdoğan has claimed that SCO is more powerful and better than European Union, and Turkey has common values with SCO member states (Wang, 2016). In this sense, TurkeyChina and Turkey Central Asia relations are very important and these relations encloses a large scale of political, economic strategic opportunities. China is also content with having close relations with Turkey. When President Erdoğan visited China, Chinese President Xi has stated that "The development of China-Turkey strategic and cooperative relations is in the fundamental interests of the two nations. The two sides should respect and each other's coordinated core concerns and deepen security and anti-terrorism cooperation" (Yue, 2017).

Turkey and SCO have common interests in geo-politic and security of the Middle East and Central Asia. As raising energy requirement and increased terrorist actions taken into account, the assurance of safety and peace is getting more important for Turkish and SCO Members' interests. Turkey is thought to be a gate open to Europe and Middle East. Turkey has a big significance in controlling Eurasia's strategic passages and BRI routes. Turkey aims to be more active in East and West politics and balance its Western and Eastern politic economic relations and take a bridge role between Asia and Europe and Middle East. Despite Turkey's these objectives, Turkey did not get an important progress in the SCO yet. However, Turkey seems want to be an important actor in the SCO and protect its Central Asia interests, so as not to be affected by possible Russian-Chinese conflicts.

\section{CONCLUSION}

Russia and China both aim to increase their influence in Central Asia, Russia majorly aims to 
increase its political influence in this region, while China is more thinking about its economic influence. On the other hand, expansion of SCO is also increasing SCO's international influence, with the accession of India and Pakistan, SCO has included four nuclear powers. This expansion is likely to generate some concerns about a full-fledged cooperation among the member states as well. The biggest concern is about the political economic competition between China and Russia; as well as the issues between Pakistan-India, and India-China. Thought SCO policies majorly being conducted parallel to China's foreign policy. However, it is not clear that how Russia, India and Pakistan will react to this state of affairs in the future. China and Russian competition probably will continue, this may deteriorate the SCO cooperation too. Here, what is should be concerned for Turkey is, how Turkey and Central Asia relations will be effected by a possible Chinese-Russian interest based conflicts.

Recently, Turkey's role in Central Asia is increasing, Turkey have close relations with Central Asia and Turkey wants to be closer to the Central Asia by having a certain position in the SCO. Turkey has declared its intention to be a member of SCO several times. By doing this, Turkey is not likely that wants to drop its bids for EU membership completely. Contrary to former policies, Turkey wants to balance its Western and Eastern relations by establishing more multilateral relations. Due to its geo-strategical position and its economic energy based politics, it is necessary for Turkey to have multilateral relations as well as being a member of different international organizations. Turkey has an important role for the future of China's BRI, Russia's and other SCO Member States' energy relations. Turkey is interested in every step of Central Asia and Central Asia's any possible conflict, probably will affect Turkish regional interests as well.

\section{REFERENCES}

Abigail, Grace (2016), "Quantifying China's Influence on the Shanghai Cooperation Organization”, Cornell International Affairs Review, Vol. 10 No:1.

Albert, Elanor (2015), "The Shanghai Cooperation Organization, counsel on foreign relations", October 14, 2015 https://www.cfr.org/backgrounder/shanghai-cooperationorganization, (Last visited 14.01.2019)

Alimov, Rashid (2018), “The Shanghai Cooperation Organization: Its role and place in the development of Eurasia", Journal of Eurasian Studies, 9.

Allison, Roy (2018), "Protective Integration and Security Policy Coordination: Comparing the SCO and CSTO”, The Chinese Journal of International Politics, Oxford University. 
Aris, Stephen (2013), “Shanghai Cooperation Organization, Mapping Multilateralism in Transition”, International Peace Institute, December, 1-3.

Baizakova, Kuralai I. (2013), “The Shanghai Cooperation Organization's Role in Countering Threats and Challenges to Central Asian Regional Security”, Russian Politics \& Law, $51-1$.

Belarusian Diplomatic Service (2019), “Collective Security Treaty Organization", http://mfa.gov.by/en/organizations/membership/list/cddd96a3f70190b1.html, （Last visited 14.11. 2019).

Çeviköz, Ünal (2016), “Turkey in a Reconnecting Eurasia, Foreign Economic and Security Interests", Center for Strategic \& International Studies (CSIS), April.

Davutoğlu, Ahmet (2010), "Rekabet Değil İşbirliği Coğrafyası İstiyoruz”, Stratejik Düşünce Dergisi, Kasım, 14-18.

Eren, Erdem (2017), "Shanghai Cooperation Organization and Future Perspective in Turkish Foreign Policy”, Strategic Public Management Journal, Volume 3, Issue 5, 77-94.

Erkin, Ekrem (2012) “Türkiye Çin ilişkileri”, Stratejik Düşünce Dergisi, Mayıs, 43-45.

Erşen, Emre (2015), “Türk Dış Politikasında Avrasya Yönelimi ve Şanghay İşbirliği Örgütü”, Ortadoğu Analiz, Vol 5, No 52.

Frost, Alexander (2009), "The Collective Security Treaty Organization, the Shanghai Cooperation Organization, and Russia's Strategic Goals in Central Asia”, China and Eurasia Forum Quarterly, Volume 7, No. 3.

Hasnat, Syed Farooq and Zamurrad Awan (2016), "Shanghai Cooperation Organization as a Platform for Regional Understanding: Its Economic, Political and Security Potential”, Perceptions, Spring, Volume XXI.

Kaczmarski, Marcin (2007), "Russia Attempts to Limit Chinese Influence by Promoting CSTOSCO Cooperation", The Central Asia-Caucasus Analyst. http://www.cacianalyst.org/publications/analytical-articles/item/11497-analyticalarticles-caci, (Last visited 29.10.2019).

Kadılar, Rıza and Erkin Ergüney (2017), “One Belt One Road Initiative: Perks and Challenges for Turkey", Turkish Policy Quarterly, Vol. 16-No.2. 
Kalra, Prajakti and Siddharth S. Saxena (2006), "Shanghai Cooperation Organization and Prospect of Development in the Eurasia Region", Turkish Policy Quarterly, Vol 6, No 2. Kazantsev, Andrey A. (2014), "Russian policy in Central Asia", pp. 1073; Weiqing Song, Interests, "Power and China's Difficult Game in the Shanghai Cooperation Organization", Journal of Contemporary China, (2014), 23-85.

Liu, Yue (2019), “Turkey to strengthen cooperation under B\&R Initiative”, 2017-05-14, Xinhua News, https://eng.yidaiyilu.gov.cn/qwyw/rdxw/13223.htm. (Last visited 8 April 2019).

Marketos, Thrassy N. (2009), “China's Energy Geopolitics: The Shanghai Cooperation Organization and Central Asia", Routledge, London and New York.

Norling, Nicklas and Niklas Swastrom (2007), “The Shanghai Cooperation Organization, trade, and the roles of Iran, India and Pakistan," Central Asian Survey, Vol 26, No 3.

Pakistan Defence Forum: July 13, 2018, https://defence.pk/pdf/threads/turkey-and-pakistan-inkdeal-for-the-sale-of-30-atak-helicopters.567559/ (Last visited 18 October 2018).

SCO official web site, http://eng.sectsco.org/about_sco/(Last visited 01/09/2017).

Snyder, Jack (2004), “One World, Rival Theories”, Foreign Policy, 145.

Song, Weiqing (2014), "Interests, Power and China's Difficult Game in the Shanghai Cooperation Organization", Journal of Contemporary China, 23-85.

Tezcür, Murat Güneş and Alexandru Grigorescu (2014), “Activism in Turkish Foreign Policy: Balancing European and Regional Interests”, International Studies Perspectives, Loyola University Chicago.

Tiezz, Shannon (2014), "The New, Improved Shanghai Cooperation Organization”, The Diplomat, September 13, 2014. https://thediplomat.com/2014/09/the-new-improvedshanghai-cooperation-organization/, (Last visited 29.01.2019).

Üngör, Cagdas (2013), “Turkey and the Shanghai Cooperation Organization: Few Shared Values and No Common Destiny", Middle East institute, https://www.mei.edu/publications/turkey-and-shanghai-cooperation-organization-fewshared-values-and-no-common-destiny, (Last visited 05.02,2019).

Wang, Lina (2016), "Will Turkey Join the Shanghai Cooperation Organization Instead of the EU? ", The Diplomat, November 24, https://thediplomat.com/2016/11/will-turkey-jointhe-shanghai-cooperation-organization-instead-of-the-eu/, (Last visited 6 January 2019). 
Wuensch, Camilla (2015), “Turkish Stream: Ankara Trying to Balance East and West”, Center for Strategic \& International Studies (CSIS).

Yıldırımçakar, Emrah (2019), "BRI And An Outlook Of Turkey-China Relations”, International Social Sciences Studies Journal, Vol 5, No 40: 3889-3901. 